Canadian University Music Review

Revue de musique des universités canadiennes

\title{
Michael Thomas Roeder. A History of the Concerto. Portland, Oregon: Amadeus Press, 1994. 480 pp. ISBN 0-931340-61-6 (hardcover)
}

\section{Glen Carruthers}

Volume 17, numéro 1, 1996

URI : https://id.erudit.org/iderudit/1014695ar

DOI : https://doi.org/10.7202/1014695ar

Aller au sommaire du numéro

Éditeur(s)

Canadian University Music Society / Société de musique des universités canadiennes

ISSN

0710-0353 (imprimé)

2291-2436 (numérique)

Découvrir la revue

Citer ce compte rendu

Carruthers, G. (1996). Compte rendu de [Michael Thomas Roeder. A History of the Concerto. Portland, Oregon: Amadeus Press, 1994. 480 pp. ISBN 0-931340-61-6 (hardcover)]. Canadian University Music Review / Revue de musique des universités canadiennes, 17(1), 98-107. https://doi.org/10.7202/1014695ar

All Rights Reserved (c Canadian University Music Society / Société de musique des universités canadiennes, 1996
Ce document est protégé par la loi sur le droit d'auteur. L'utilisation des services d'Érudit (y compris la reproduction) est assujettie à sa politique d'utilisation que vous pouvez consulter en ligne.

https://apropos.erudit.org/fr/usagers/politique-dutilisation/ 


\section{BOOK REVIEWS/COMPTES RENDUS}

Michael Thomas Roeder. A History of the Concerto. Portland, Oregon: Amadeus Press, 1994. 480 pp. ISBN 0-931340-61-6 (hardcover).

This book constitutes the first full-length study in English of the history of the concerto since Abraham Veinus's book, The Concerto, appeared in 1948. It goes without saying that Veinus's book has needed replacing for a very long time and so the present publication is most welcome.

Two related questions confront any author who undertakes to chart the development of a genre from its inception to the present day. The first, "For whom is the book intended?", will determine the depth of coverage. The second, "What works will be included/excluded?", will determine its scope. The answers to these questions are, with respect to the present volume, not easy to ascertain.

Roeder feels it is necessary to define terms like homophonic and hemiola, to explain the use of Roman numerals to denote scale degrees, and to explain that a clarinet is a single-reed instrument. On the same page that hemiola is defined, it is taken for granted that the reader knows what "chains of 2-3 suspensions" and "Phrygian cadences" are. It is further assumed that such observations as "the final chord, the dominant, is approached by the subdominant chord in first inversion, resulting in the characteristic bass movement of a descending semitone from the minor sixth scale degree to the dominant" will be understood (p. 30). A few pages later, it is assumed that the reader is aware of the distinction between diatonic and chromatic sequences.

It seems to me that the reader able to cope with suspensions, modal and tonal cadences, and diatonic and chromatic sequences, should know what homophony and hemiola are. Conversely, if homophony is a new concept, then probably so are suspensions, minor sixth scale degrees, and chromatic sequences. And here in a nutshell is the problem; when things are kept interesting for the music student or professional musician, more casual readers will be hopelessly left behind. When terms and concepts are explained for the casual reader, students and others are apt to become bored. In trying to be all things to all people, the book ends up satisfying no one completely. To be told on page 103 that the term "dynamics" refer to "the relative volume of sound" is downright silly. No one is going to make it through 100 pages into this sort of book without knowing what "dynamics" means.

The emphasis in the early parts of the book on relatively obscure composers is gratifying, except that the same kind of attention is not given to parallel composers from the nineteenth century. Minor composers, such as Leonardo Leo (1694-1744), who Roeder admits "is unlikely [to have] exerted any influence on contemporary or succeeding composers" (p. 30), and who is 
inexplicably omitted from the index, Pietro Nardini (1722-1793), Pierre Gaviniès (1728-1800) and G. M. Giornovichi (c. 1740-1804) each receive their own little sections in the chapter on the early Classical concerto. Even still lesser lights, like Ludwig A. Lebrun (1752-1790) and Jean-Baptiste Sébastien Bréval (1753-1823) rate a mention. In the early Romantic era, Roeder manages to mention Weber's Six Variations on a Folksong for Viola, the Grand Potpourri for Cello and Andante e Rondo Ungarese for Viola (and later arranged for bassoon), which he characterizes as "in the main, shallow in substance and lacking in any significant redeeming musical qualities" (p. 217). This assessment seems rather harsh, but so be it. What is disconcerting is that, in finding room to mention these pieces, and in devoting an entire page to Schumann's Violin Concerto (although its last movement only gets one sentence) or three pages to Dvořák's Violin Concerto, Roeder overlooks some important works of enduring value; Dohnányi's Variations on a Nursery Song, for example, is not mentioned. Moreover, to mention the Sérénade mélancolique and ValseScherzo of Tchaikovsky is fine, but not at the expense of the structurally fascinating Concert Fantasy for piano and orchestra, which is not even listed, let alone discussed. Other works that do not rate a mention include Szymanowski's two violin concertos $(1916,1933)$, Busoni's Divertimento for flute and orchestra (1920), Vaughan Williams' Flos Campi for viola, orchestra, and chorus (1925), Ponce's Concierto del Sur (1941), Rodrigo's Fantasia para un gentilhombre (1954), several other important works for guitar and orchestra, Korngold's Concerto in D for violin and orchestra (1946) (why is Victor Herbert but not Korngold discussed?), William Schuman's Song of Orpheus (Fantasy for cello and orchestra) (1961), and Penderecki's Capriccio for violin and orchestra (1967).

In the section on Canada, it seems inconsistent to discuss Jean PapineauCouture's Pièces concertantes but to omit mention of John Weinzweig's Divertimentos. It is no doubt symptomatic of Roeder's biases that fellowAlbertans Violet Archer and Malcolm Forsyth together rate a page, but that other composers of important concertos, like S. C. Eckhardt-Gramatté from Winnipeg, are not mentioned. This does seem a serious omission, in that her Triple Concerto, Bassoon Concerto and Symphony-Concerto have been recorded commercially.

Even within the output of a single composer, Roeder's choices of works to discuss are sometimes perplexing. There are eighteen pages devoted to Vivaldi and the mature baroque concerto, but it is regrettable, after acknowledging that Vivaldi composed almost forty bassoon concertos (although later Roeder states misleadingly that Vivaldi "composed a few concertos for winds" (p. 30)) and many concertos for unusual instruments (e.g., mandolin, trombon da caccia, theorbo) and unusual combinations of instruments (e.g., viola d'amore and lute), that the author only selects for individual attention works for strings, including the ubiquitous The Four Seasons. I suppose it is inevitable that the author's predilections, too, are reflected in the disparity in emphasis given to two important works by the same composer. I find it difficult to understand 
why Bartók's Second Piano Concerto rates more than a page and a half, while the Third is allotted a single paragraph.

Also of concern is the extent to which Roeder adheres to the long-established canon, particularly with respect to nineteenth-century music, to the extent that many significant composers whose works are now readily available on recordings are overlooked. I'm thinking mainly of Medtner, but also Thalberg, Henselt, Alkan, Litolff and others. It is these composers who have been excluded so that such marginal figures in the history of the concerto as Webern may be included. Webern is given three entire pages, but the only work that is even vaguely appropriate to the topic at hand is the Concerto for Nine Instruments, which, it could be argued, is not particularly important as a concerto. Roeder admits, in the context of what amounts to a short history of twentiethcentury Italian music, that Dallapiccola "paid little attention to the concerto" and that Luigi Nono "has neglected the concerto" (both, p. 400). A few pages later, Roeder informs us that Janáček's Concertino for seven players "is more a piece of chamber music than a true concerto" (p. 406). But, nonetheless, Dallapiccola and Nono are mentioned and Janáček is given a paragraph, while Medtner and company do not appear at all.

In light of Roeder's cursory review of some important works by major composers and of the omission of some significant composers, it was refreshing to find that Hummel, whose reputation seems to be undergoing some rehabilitation these days, is accorded a full three pages, with emphasis on the Piano Concerto in B minor, so brilliantly recorded by Stephen Hough in 1986. More surprises await in the next chapter. In assessing the relative worth of Spohr and Weber, Roeder believes the former displays "more restrained musical expression and greater inward thoughtfulness" than the latter (p. 209). Roeder's point is well taken, if not as it applies to the whole of Weber's output, at least when it comes to concertos. In this genre, Spohr is at least Weber's equal. Less obvious is what Roeder has in mind, after surveying the concertos of both composers, when he asserts that "Weber's single greatest contribution to the concerto ... was the creation of a brilliant new program-driven form found in his Konzertstück" (p. 220). I'm not so sure that point could be argued convincingly. Weber's greatest contribution to the genre is undoubtedly the Konzertstïck, but did the form and nature of the work have much influence? Perhaps Roeder could have told us what other program-driven works, influenced by Weber, he had in mind.

In innumerable instances, a little bit of elaboration would have gone a long way. Roeder dismisses Beethoven's slow movements by noting, with reference to the "Emperor Concerto," that "the slow movement is comparatively brief, since the tempo is not well-suited for virtuoso showmanship" (p. 190). It is the word "comparatively" that is significant here; it is not that the slow movement is short, but that the first movement is long. And surely Beethoven did not always have virtuoso showmanship uppermost in his mind. Two pages later Roeder informs us that "Beethoven ... lavished much attention on his slow movements, which typically are complex and profound" (p. 192). Are not these two viewpoints diametrically opposed? 
Many occasions arise where just a line or two more, or more numerous endnotes, would have helped considerably. In the chapter on the concerto in the Soviet Union one is left wondering which "pair of works by Shostakovich" was condemned in 1936, in which movement or movements the flexatone appears in Khachaturian's Piano Concerto, to what key the first variation of the second movement of Rachmaninov's Third Piano Concerto "veers off" unexpectedly, which piece by Prokofiev received devastating criticism to which the composer responded with the Second Violin Concerto, and so on. I also think, no matter how highly one regards Brahms, that it is misleading for students to read that Brahms's use of rhythm "marks him as one of the most progressive of the nineteenth-century composers" (p. 259). Perhaps in this one regard and, indeed, in other regards, this is true, but a few corroborating statements from Schoenberg, or Roeder, would have been desirable.

Sometimes it is not so much that Roeder does not give us enough information, but rather that he seems a bit unsure of himself. With reference to Bach's Brandenburg Concerto No. 1, Roeder speculates that, at the final cadence in the adagio, "perhaps a soloist was expected to improvise embellishments ..." (p. 86). A paragraph later, Roeder "wonders if the soloist might have been expected to elaborate [the] Adagio with improvisation ..." (p. 86). Not only is this a little too much speculation for one half-page, but a reference to relevant literature on the topic would have been very helpful. As it is, the reader can only wonder along with Roeder, without knowing where to turn for a more definitive or more detailed answer. When it comes to Liszt, Roeder notes that by 1842 he "had become so popular that a kind of mass madness known as 'Lisztomania' swept Europe" (p. 240). That may be, but does Roeder mean to imply that the term "Lisztomania" was current in Europe in the mid-nineteenthcentury? Some documentation would have been instructive for readers like myself who had presumed "Lisztomania" - the word, not the phenomenonhad more to do with Ken Russell than with the nineteenth century.

The documentation is ample for the casual reader, but far too sparse for students and others. Roeder tells us that "evidence for the use of concerto grosso instrumentation in the late 1660s exists" (p. 24), but we search in vain for an explanation, either in the body of the book or in an endnote, of just what that evidence is. Later on we are told that Alfred Einstein believed the earliest of Mozart's concertos to be the K. 107 arrangements. Has subsequent scholarship not proved Einstein correct? In connection with Corelli's concerti grossi we are told that lead-in cadenzas, which are highly effective in introducing the soloist, are found, "in some of [Mozart's] piano concertos a century later" (p. 29). Neither elaboration, nor footnote, is given. I flipped ahead to the chapter on Mozart and found the same statement, but again without an example. Next stop was the index, where under Mozart a reference to lead-in cadenzas refers to page 29, which is where our quest began. We have come full circle without an answer. Regarding Bach, we are told that Telemann was a model for one of the solo keyboard transcriptions and that, like Telemann, Bach used interesting combinations of instruments in his concertino groups. I then went to look up Telemann, since I know nothing of his concertino preferences, only to find that 
Telemann is not discussed at all. None of his almost 100 concertos is even mentioned. Other omissions are less significant, but nonetheless vexing. It is explained that Mozart's Concert Rondo, K. 382 is the alternate finale to the Piano Concerto in D major, K. 175, but the Concert Rondo, K. 386 is glossed over. We learn that the slow movement of the Piano Concerto in B-flat major, K. 450 represents Mozart's "first use of variation form in the concertos, aside from the Rondo, K. 386" (p. 157). From this we can presume that K. 386 has something to do with the concertos, but exactly what is never explained (it was likely intended as an alternate finale to K. 414). Similarly, Josef Antonín Štěpán (p. 1726-1797) "anticipated important Romantic tendencies in his later concertos. For example, he used a large, expressive slow introduction in the minor key in which the soloist participates ..." (p. 119). It would have been helpful for students to know which Romantic concertos, beginning with "large, expressive slow introductions," Roeder had in mind; likely, among others, Beethoven's "Emperor" Concerto and Tchaikovsky's First Piano Concerto. Roeder reiterates his point again in Chapter Twelve; again, no examples are given. It is in Chapter Thirteen that Roeder returns in some detail to this issue, positing that many of the one-movement works for solo instrument and orchestra written in the nineteenth century are, in fact, conventional concertos without a first movement, and this may be what Roeder was thinking of all along. I did think Roeder's view of the genesis of these one-movement pieces to be both novel and perceptive.

One composer who is given a great deal of credit, I believe justifiably, is Mendelssohn. Roeder credits Mendelssohn with finding a solution to a shortcoming inherent in the works of his immediate predecessors, namely, the often unimaginative but seemingly obligatory opening tutti. It is Mendelssohn who dispenses with this outworn feature of concerto- sonata form, replacing it with a standard sonata-allegro movement in which the soloist is given thematic substance from the outset. This aspect of Mendelssohn's works, combined with their modest cyclic elements, are important harbingers of later Romantic concertos. Unfortunately, no sooner does Roeder giveth, than he taketh away. $\mathrm{He}$ speculates that the conciseness of the opening movement of the Piano Concerto in G minor, one of Mendelssohn's finest concerto movements and one which points ahead to Liszt in its emphasis on the solo instrument, may have been purely pragmatic: "One wonders if [the] rush to ready a piece for performance in Munich may have motivated him to compress the first movement by eliminating the major tutti sections" (p. 229).

In any event, Mendelssohn, like Hummel, is given his due. The same cannot be said of other composers who are included but whose works are dealt with so superficially that one wonders why they were included at all. After a few chapters, Roeder's insistence on saying something about each movement of each concerto he discusses begins to try the reader's patience. A single sentence is devoted to the slow movement of Bach's Sixth Brandenburg Concerto, to the final movement of his Harpsichord Concerto, BWV 1056, to the finales to Mozart's Piano Concertos K. 414 and 482, to the slow movement of Haydn's Violin Concerto in C major, Hob VIIa:4, to the scherzo of Prokofiev's Second 
Piano Concerto, to the finale of Barber's Violin Concerto, and so on. The splendid slow movement of the Italian Concerto rates only the following comment: "The slow movement is another of Bach's cantilenas" (p. 100). Even the exquisite largo of Beethoven's Piano Concerto in C minor, op. 37, like the adagio of Bruch's Violin Concerto, is reduced to a single sentence. In other instances, such as Mozart's Piano Concerto in B-flat major, K. 456, two movements, the second and third, are covered by one sentence. Entire works, like Mozart's Horn Concerto, K. 495, rate only a single sentence: "The last of the horn concertos ... is the most technicaly demanding, with its rapid runs, frequent use of stopped notes, and cantabile passages in the upper register" (p. 152). By the end of the book, matters have gone from bad to worse. The second and third movements of Stravinsky's Concerto for Piano and Winds each rate one sentence, another sentence deals with all three movements of Barber's Cello Concerto, another sentence takes care of Hanson's organ and piano concertos, Paul Creston's three concertos are dealt with in one sentence, and Charles Wuorinen is given only one sentence in toto.

In other connections, it is true that Roeder's brevity is a virtue. He is at his best when creating succinct comparisons; Albinoni's concertos are homophonic, his sonatas are polyphonic; in ritornello form, motives are "used like building blocks, a form of construction which stands midway between the Baroque technique of spinning out one theme and the Classical practice of developing independent themes" (p. 50). One of these pithy and useful comparisons is the source of some confusion. Roeder explains that in rondo form the theme returns in the tonic key, but that in ritornello form the theme recurs in different keys. This seems very clear. Unfortunately, the distinction becomes blurred later on, in connection with the First Brandenburg Concerto, when Roeder notes that the concluding minuet "alternates in rondo (or ritornello) fashion with other dances" (p. 86). According to Roeder's own definition, these terms are not interchangeable; since the minuet always recurs in the home key the movement is, in fact, in ritornello form. Trying to relocate Roeder's distinction between rondo and ritornello forms helped to identify a shortcoming in the index. Whereas the entry for "ripieno", which immediately precedes that for "ritornello," has a sub-listing for "definition of," there is no such sub-listing under the entry for ritornello. It is under the sub-listings "introduced by Torelli" and "in Vivaldi" that the term is defined. Surely an entry reading "ritornello, definition of" and making reference to pages 38 and 49 is not only needed, but absolutely necessary under the circumstances.

Generally, Roeder's overviews of stylistic developments are remarkable for their focus and clarity and are among the highlights of the book. His exhaustive overview of the development of concerto first-movement form is as lucid as it is useful. The comparison of J. C. Bach's "first-movement" and "concertosonata" forms, rendered by means of charts on pages 121,123 and 125 , is crystal clear and helps the student to understand a tremendously important stage in the evolution of the concerto. Again, in his discussion of mature concerto-sonata form, Roeder has recourse to a chart which elucidates matters 
considerably. Roeder also clarifies in a few short paragraphs the nature of $\mathrm{J}$. C. Bach's influence on the young Mozart.

The chapter on Mozart is, overall, one of the most satisfying in the book. This may be because Roeder relaxes his cataloguing of concertos and their distinctive features long enough to draw some interesting parallels between Mozart's early and later works (as he had done in his discussion of J. C. Bach, another of the book's stronger sections) and to find presentiments of romantic style in the cadenzas to Mozart's mature piano concertos and, less obviously, in the finales to his violin concertos. Clear, too, is Roeder's discussion of what makes Beethoven's Second Piano Concerto similar to, but different from Mozart.

The author is also good distilling from a varied group of works a few essential points. His recipe for a Bach solo keyboard transcription is succinct and accurate, and his observation that the Brandenburg Concertos represent Bach's most successful synthesis of Italian and German goes straight to the point. By reading the opening sections to chapters Twelve through Sixteen the reader can get a very good sense of the development of the nineteenth-century concerto, from its solo-dominated beginnings to the more symphonic conceptions of Schumann and Brahms. I found Roeder's discussion of Brahms quite interesting, and the comparison between Brahms's and Mozart's minor-key piano concertos is illuminating. I did find it strange that no mention was made of Joachim's Concerto in Hungarian Style with reference to the finale of Brahms's Violin Concerto.

I derived considerable pleasure from Roeder's one-line zingers, that state simple but often overlooked facts; how many readers are aware that Spohr invented the chin rest; that Grieg began a second piano concerto fifteen years after completing his famous A minor concerto; that Milhaud wrote thirty concertos; that Hindemith wrote a left-hand work for Paul Wittgenstein, which is now lost? It had never occurred to me that Schumann's was the first cello concerto by a major composer since Haydn and I had no idea that Mozart had written five bassoon concertos and a cello concerto. Also striking is Roeder's observation that "the harpsichord concerto remained virtually the exclusive property of the Bach family until around 1750" (p. 98).

Roeder is able, in a few paragraphs, to lay the foundation for a discussion of a whole school or schools of composition. The introduction, dealing with Glinka, Rubinstein, Balakirev, and Rimsky-Korsakov, to the chapter on the concerto in Russia, establishes important groundwork for the ensuing discussion of Tchaikovsky and Rachmaninov. Incidentally, the reader is led to believe that Tchaikovsky planned to dedicate his First Piano Concerto to Nicolas Rubinstein, which is not true. The dedicatee was to be Serge Taneyev. Less excusable is Roeder's statement concerning Rachmaninov's and Horowitz's cuts to the former's Third Piano Concerto. Roeder writes that "thankfully, several modern performers are now capable of performing the entire work in its original form" (p. 306), clearly suggesting that Rachmaninov and Horowitz were incapable of playing the work as written, which is nonsense. 
The chapters on Russian and Soviet repertoire are intelligently positioned, so that Rachmaninov concludes discussion of the nineteenth-century concerto and the Soviets initiate discussion of the twentieth-century concerto two chapters later. The intervening chapter, entitled "The Twentieth Century: An Introduction," makes for informative reading. Roeder's position that early twentieth-century styles represent facets of Romantic music, isolated and expanded upon, is quite convincing; Roeder even sees serialism and indeterminacy as natural outgrowths of contradictory nineteenth-century values, control on the one hand and spontaneity on the other. These are interesting viewpoints and the reader is left wishing the book contained more provocative morsels, rather than page after page of descriptions of music, which serve no useful purpose except to provide a road map for listeners, which is what program notes, not monographs, are expected to do. These blow-by-blow descriptions would have been more tolerable had they somehow captured the spirit of the music. However, none of the humour of Vivaldi's score comes across in the author's recounting the programmatic elements in The Four Seasons. From reading through Roeder's descriptions, one gets the impression that Vivaldi's is a workaday effort and that naïve extra-musical associations are its only raison d'être. Lacking is any sense of the wonderful technical and musical innovations that are embodied in these works and that have endeared them to so many listeners. This problem runs throughout the book, so that Roeder fails to capture the excitement of what must surely be one of the most electrifying of all twentieth century works for a soloist and orchestra, the Piano Concerto (1961) of Alberto Ginastera.

It is well and good to have the power of one's convictions, but this can become a liability. Roeder's opinion is that Beethoven made an error in having the opening ritornello of the Third Piano Concerto end in the tonic key, thereby undermining the power of the soloist's first entry. Fine. But does this really need to be reiterated every time a composer commits the same so-called lapse? It comes up with respect to Chopin, Schumann and Dvořák, and the reader is left wondering that, if this sort of opening was good enough for Beethoven, Chopin, Schumann, and Dvorák, perhaps it is Roeder who has missed the point.

Mention must be made of the gratuitous summations that conclude several chapters. The summation at the end of Chapter Two would be at home in an appreciation text, but seems seriously out of place in an historical study: "In sum, Corelli's concerti grossi are carefully wrought compositions that repay serious listening with deep pleasure" (p. 35). Or try this from the end of Chapter Three: "Albinoni's instrumental music has an ingratiating style that is most appealing to listeners" (p. 44). These throw-away sentences serve to diminish the significance of the discussions they conclude. If what we learn from the examination of Brahms can be summed up by observing that " $[\mathrm{Brahms}]$ created concertos with deeply satisfying musical content" (p. 272), the depth of the examination is called into question. The section on the concerto in the Soviet Union concludes with the observation that "in spite of the political gulf that existed between East and West, this music speaks directly to the hearts of listeners the world over" (p. 325). Do we really need to be told this? Nor are 
these sorts of self-evident truths confined to conclusions. How else would one create a "luxuriant orchestral texture" if not by the "effective use of orchestral instruments" (p. 326)? Or how can "bitonal colouring" be achieved if not by "using two keys at once" (p. 333)?

The reader is struck as early as Chapter Three by the sameness in approach to each composer. A brief discussion of the "school" or tradition from which a composer develops gives way to a thumbnail biography, followed by the analysis of a few works and a short conclusion. Then on to the next composer, be it Stradella, Torelli or Albinoni. In the early chapters, it is only when Roeder is struck by the exceptional historical significance of a composer-Corelli, for example-that he departs from this formula.

The plethora of descriptive adjectives may also have a place in an appreciation text, but in the present context come across as filler. What is the reader to make of Roeder's description of the finale of Mozart's Piano Concerto in D minor as, by turns, powerful and thrusting, jaunty, playful, agitated, lyric, jaunty (again), amusing and happy. This sort of writing pervades the book; elements in Walton's Viola Concerto are described as jumpy, jazzy, lively, calm, urgent and dreamy. The reader is left wondering if these sorts of subjective descriptions are in any way helpful.

The number of modifiers and qualifiers employed throughout the book is also disconcerting. The harmonic rhythm in Gabrieli's works is rather regular and the melodic ideas in Vivaldi's concertos are relatively spontaneous-sounding. Elements in other works are quite improvisatory, fairly distinctive, fairly lengthy, fairly strict and quite effective. And what is the student to make of such fence-sitting observations as Vivaldi played "a greater or lesser role" (p. 52 ) in the development of the cadenza or Vivaldi "must quite surely have been influenced by [Albinoni]" (p. 42)? Must quite surely? Would not "must have been influenced" have done the trick?

Stylistic influences are sometimes difficult to pin down, but Roeder too frequently leaves the ball in the listener's court. The scherzo of Saint-Saëns Second Piano Concerto "may remind the listener of [Mendelssohn]" (p. 287), part of Tchaikovsky's First Piano Concerto "may remind listeners" (p. 285) of Romeo and Juliet, the slow movement of Prokofiev's Second Violin Concerto "may remind some listeners" (p. 321) of Mozart's K. 467, an episode in Vaughan Williams's Piano Concerto "may remind listeners of Liszt's Mephisto Waltz" (p. 332), the slow movement of Elgar's Violin Concerto "reminds some of the slow movement of Brahms's Violin Concerto" (p. 328) and Schoenberg's Piano Concerto "reminds some of the music of Brahms" (p. 370). I don't think, by the way, that Roeder means to say that the climax before the cadenza in the finale of Elgar's Violin Concerto "fizzles" (p. 329); could he mean "sizzles"? Roeder opines that the openings of Elgar's and Walton's Cello Concertos "imitated" Schumann's. Yes, there is a similarity, but most readers would need documentation, or at least more convincing evidence, before buying into the notion of imitation. Prokofiev's First Violin Concerto "may have provided the inspiration for Walton's Viola Concerto" (p. 318), but since nothing more is said of the matter, the reader is left hanging. 
The layout and format, especially in light of the vast scope of this book, are excellent. In the earlier chapters, works that receive a page or two of analysis are given their own headings, but in later chapters this convenience is dispensed with. I do question the merit of placing discussion of the concerto in Britain before the chapter on Scandinavian music. Because of this arrangement, we read of Peter Maxwell Davies, for example, before Sibelius. Since Roeder begins the chapter on Scandinavian music with the observation that "The history of music in Finland parallels that of Russia" (p. 346), why not have put the chapter on Scandinavia after that on Russia, thereby dealing with Rachmaninov and Sibelius, logically, in succession? Then the Soviets could still have led the way into the twentieth century. I also found the return to Dvořák at the end of the section on the United States out of place, and that far too much emphasis-nine pages-is placed on jazz-inspired concertos. It would have been advisable to refer readers interested in jazz-inspired works back to Norman Symonds in the preceding chapter, lest it be thought that so-called third-stream composition is uniquely American.

There are a few awkward sentences here and there, but generally structure and syntax are beyond reproach. I do think "... horns and woodwinds present the theme, giving it the colour of its horn-call character" (p. 255) could have used a little work. I also found the translation "Concertstück for Four Horns," in reference to Schumann's exquisite work, very awkward; "Konzertstück" or "Concert Piece" makes sense, but the hybrid English-German "Concertstück" is no more logical than "Konzert Piece" would be. Typos are at an absolute minimum; I found a few missing words, punctuation marks and accents, but that's about it, which is remarkable in such a lengthy book, until the chapter on the concerto in Canada. The copy editor seems to have fallen asleep at the end of page 415, so that two typos appear in successive lines. It is unfortunate that these typos involve the names of important Canadian musicians, so that generations of students, here and elsewhere, may go through life thinking that Anton Kuerti is Anton Kureti and Talivaldis Kenins is Talivaldis Kennis.

The book features many musical examples that seem to be right there when you need them and the many photographs are both welcome and expertly reproduced. I found the photo of the cast of Liszt's hand to be especially fascinating and spent some time, as I expect others will, opening and closing my own hand, stretching and pulling, wondering how Liszt's thumb could possibly be so long as to reach the second joint of the adjacent finger.

In sum, then, a handsomely produced book that helps fill a sizeable lacuna in modern scholarship. In its effort to satisfy "the enthusiastic amateur and the inquisitive lover of music, as well as the serious student, the professional musician, and the musical scholar" (p. 14), Roeder has cast his net far too widely to satisfy entirely any one of his intended markets. At the same time, Roeder has provided a useful reference work that, though I wouldn't recommend reading it cover to cover, can be useful when sampled a chapter, composer, or work at a time. 